\title{
A CLINICAL CASE OF THE TREATMENT OF THE SPINE TRAUMA WITH SPINAL CORD INJURY IN CAT
}

\author{
V. O. DOROSHCHUK, Candidate of Veterinary Sciences, Associate Professor, \\ Department of Surgery and Pathophysiology \\ named after Academician I. O. Povazhenko \\ https://orcid.org/0000-0003-2826-5740
}

National University of Life and Environmental Sciences of Ukraine, Kyiv, Ukraine A. I. SOKOL, Graduate student, Department of Surgery and Pathophysiology named after Academician I. O. Povazhenko https://orcid.org/0000-0002-2968-5934

National University of Life and Environmental Sciences of Ukraine, Kyiv, Ukraine E-mail:dorviktor@gmail.com

\begin{abstract}
The article covers a clinical case of spine trauma with spinal cord injury in a cat. He was diagnosed with a bullet wound to the lumbar spine with spinal cord compression. Dorsal laminectomy was performed with the removal of the bullet at the L3-L5 level. The surgical intervention was performed without complications with a complete recovery of the animal after 2 months.

Because the prognosis of functional recovery remains cautious in spinal cord injuries without deep pain perception, as spinal cord function is completely blocked, it is important to note that nociceptive pathways are most resistant to compression and ischemia. It is established that for the diagnosis and control of the treatment results for spinal cord injuries in cats, the most appropriate is an X-ray examination of the damaged areas in lateral and dorsoventral projections using an X-ray contrast agents (myelography).

Laminectomy, which involves the partial or complete removal of an element that causes a compression effect, allowing additional free space to form for the spinal cord, is an effective method for treating spine injuries and spinal cord traumas in cats. Additional stabilizing systems are used to fix the spine and preserve its functions. Laminectomy allows eliminating the pressure of other anatomical structures on the spinal cord of the animal and nerve endings by resection of the vertebral arches in the affected area, their spinous processes, intervertebral discs, etc. The restoration of the functional state of the animal requires a comprehensive application of rehabilitation measures, such as control of motor activity of the animal (namely its restriction), massage, physiotherapy procedures aimed at reducing pain and improving blood circulation in the injured area.
\end{abstract}

Keywords: spine, vertebra, laminectomy, cat, trauma, spinal cord 


\section{Introduction}

Currently, in Ukraine, animals are not fully protected from cruelty, so cases of trauma to small animals are common in the practice of a veterinarian. Due to the constant urbanization of polytrauma in animals are quite common. They are most often associated with a fall from a height or injury from a car accident. Due to the availability of air guns, the number of cases of bullet wounds has increased.

After a spinal cord injury, one of the main problems for cat owners is whether their cat will be able to fully recover (ability to walk, maintaining the functions of self-selection). Unfortunately, in fact, the most common is "suboptimal recovery", when weakness and urinary incontinence in animals persist forever.

\section{Analysis of recent researches and publications}

In general, in any patient with a spinal cord injury with paraplegia/tetraplegia without a deep perception of pain, the prognosis of functional recovery remains cautious because spinal cord functions are completely blocked or intersect at the site of injury (Olby, 2012). It should be borne in mind that the nociceptive pathways are the most resistant to compression and ischemia. Further examination is required to confirm the integrity of the spinal cord. Thorough neurological examination is fundamental to assess spinal cord function and provide the client with a prognosis (Zamprogno et al., 2010).

Injured animals in shock should be treated before assessing spinal cord function. Tactics for treating such animals should always be based on the assumption that the spine is unstable, so care should be taken when manipulating or moving the patient (Knipe et al., 2001). After stabili- zation of vital signs, a review radiograph ( 2 projections: lateral and dorsoventral) of the entire spine is usually performed, as approximately $20 \%$ of patients with spinal cord injury have multiple vertebral fractures or dislocations (Jeffery, 2010). Instrumental research methods may include plain radiography, myelography (contrast radiography or spondylography), computed tomography, magnetic resonance imaging. Diagnostic imaging is the most important step in making a diagnosis. However, plain radiography is characterized by low sensitivity in identifying a pathological disc (55-60\%), therefore, this method is advisable to use for screening diagnostics in order to exclude fractures (Schur et al., 2010).

Laminectomy is the partial or complete removal of an element that causes a compression effect, allowing the formation of additional free space for the spinal structures (Kranenburg et al., 2012). Additional stabilizing systems are used to fix the spine and preserve its functions (Sharp \& Wheeler, 2005). Laminectomy allows eliminating the pressure of other anatomical structures on the spinal cord of the animal and nerve endings by resection of the vertebral arches in the affected area, their spinous processes, intervertebral discs, etc. (DiFazio \& Fletcher, 2013). Thanks to these measures, it is possible to eliminate pressure on sensitive spinal structures and to release the clamped nerve endings releasing an animal from the expressed pain, and also paresthesias and paresis (Yadhati et al., 2017).

Purpose. To determine the most optimal algorithm for the diagnosis and treatment of spine trauma with spinal cord injury in cats. To raise the awareness of veterinary practitioners about the most effective methods for treating complex spine traumas with spinal cord injury in cats. 


\section{Materials and methods of research}

The private veterinary clinic in Kyiv received an animal: a cat, age 8 months, male, half-breed, with signs of trauma to the spinal canal (penetrating hole, probably a bullet in the lumbar region). The clinical examination revealed complete paralysis of the pelvic limbs, the absence of any reflexes and types of sensitivity. Research methods are clinical and instrumental (radiological). The animal underwent myelography. Before myelography, we performed neuroleptoanalgesia with Meditin at a dose of $1.0 \mathrm{mg} / \mathrm{kg}$. For premedication, we used atropine at a dose of $0.5 \mathrm{mg} / \mathrm{kg}$. Immediately after the neuroleptoanalgesia, we intubated the animal, which made it possible to immediately resort to artificial ventilation in case of respiratory arrest.

When contrasting the cerebrospinal fluid spaces of the spinal cord, a very important step is to calculate the dose of a radiopaque substance. With an increase in concentration, the quality of visualization improves but, at the same time, an increase in the concentration of contrast agents in the liquor spaces increases the risk of complications, allergic reactions, and side effects. Therefore, the choice of radiopaque contrast agents is very important. Based on our own experience, we recommend Omnipaque, which we used at a dose of $1.0 \mathrm{ml}$ per cat.

We performed the caudal approach by subarachnoid injection in the lumbar spine. For this, the animal was fixed in a lateral position by extending the cranial pelvic limbs (so that the animal's spine was in a flexed position). The injection was performed at the L5-L6 level.

Guided by the wings of the ilium, L7 was palpated, located at the level of their cranial edge, and L6, L5, and L4 were identified. Then the needle was inserted in the sagittal plane into the intervertebral space, between the two spinous processes, parallel to the caudally located spinous process. After the sensation of "falling through" of the needle (when the dura mater was punctured), the mandrel was removed and, in the presence of cerebrospinal fluid outflow, a radiopaque substance was injected (Royce et al., 1993).

Contrast radiography was performed on a mobile X-ray machine Fujifilm FCR Go 2 (Japan). Thanks to its high power (max, anode current $250 \mathrm{~mA}$ ) and a small focal spot size $(0.6 \mathrm{~mm})$, the device allows obtaining clear images with a short exposure time.

The animal underwent laminectomy. Meditin, Zoletil, and Sevoflurane were used for anesthesia. The correct position of the animal during the surgery is of great importance and facilitates its implementation.

\section{Results of the research and their discussion}

For the most accurate determination of the lesion in the spine, an X-ray examination was performed in lateral projection. After a preliminary X-ray examination in the spinal canal of the animal, a foreign body (bullet) was found in the lumbar region at the L4 level (Fig. 1).

This injury was an open penetrating fracture of the vertebral arch with a large number of fragments, which causes compression of the spinal cord at the L4 level (myelopathy), and radiculopathy due to swelling of the surrounding tissues. In this case, the vertebra itself remains stable relative to others, so it does not require additional fixation. Prolonged compression of the spinal cord can cause irreversible consequences, so medical manipulations should be performed im- 


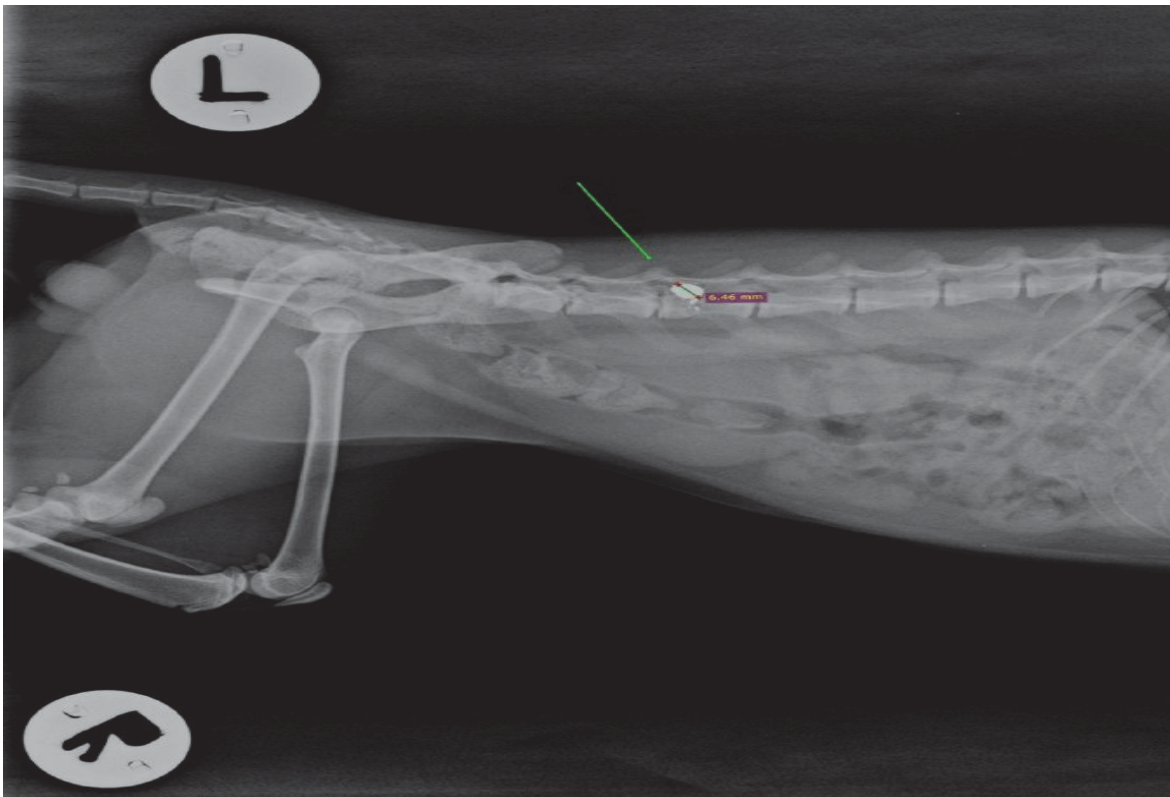

Fig. 1. Radiography of the damaged area of the spine in lateral projection

mediately. Immediately before surgery, myelography with an X-ray contrast agent Omnipaque-300 at a dose of $1.0 \mathrm{ml}$ (Fig. 2) was performed to accurately de- termine the degree of spinal cord injury, after which the presence of spinal cord compression and narrowing of the spinal canal was established.

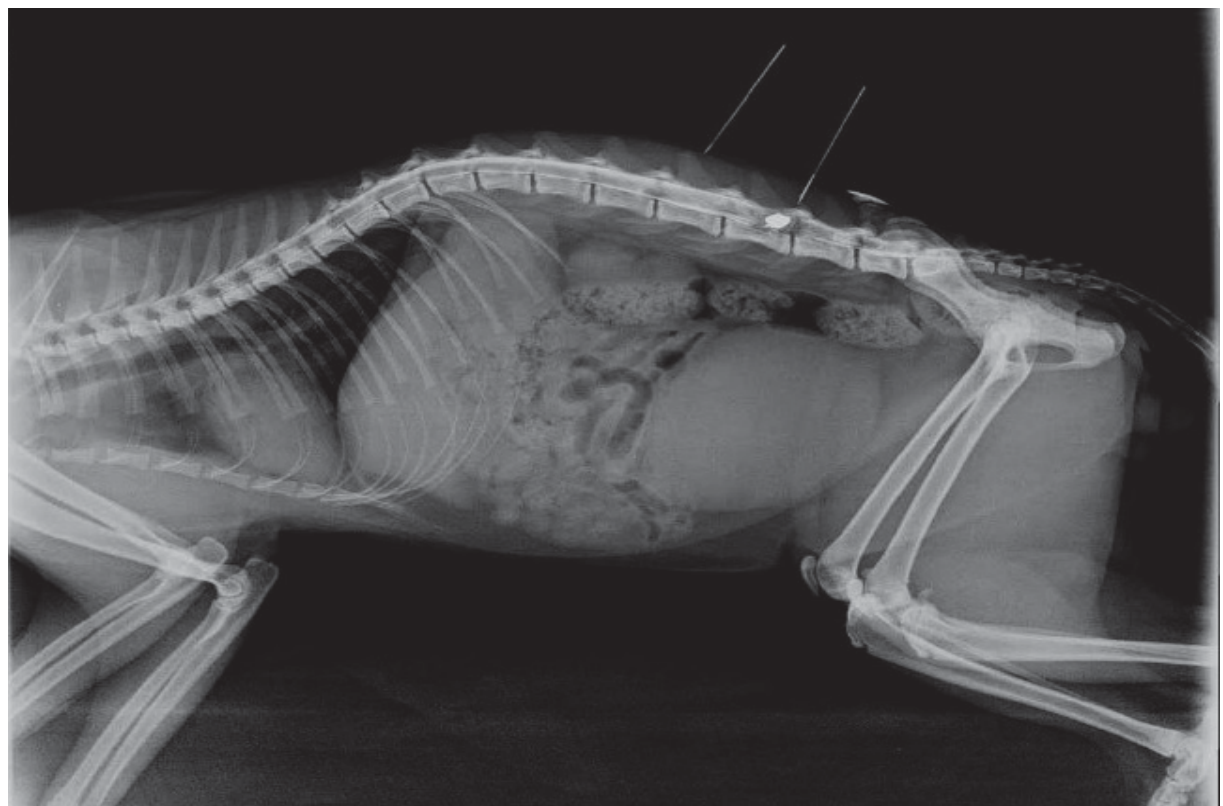

Fig. 2. Myelography of the damaged area of the spine 
This figure shows an X-ray image with a contrast agent injected into the subarachnoid space. The radiopaque substance clearly indicates the location of the spinal lesion and the violation of the integrity of the spinal canal.

We removed the bullet and fragments of the vertebral arch, as well as hemilaminectomy to reduce spinal cord compression, during which we removed parts of the arches of two adjacent vertebrae and articular processes (Fig. 3, 4).

Figures 3, 4 show the stages of dorsal laminectomy - separation of soft tissues from the arches and joints of the vertebrae; reaming the contour of the removed part of the vertebral arch with a diamond bur; removal of the vertebral arch and release of the spinal cord from compression; spinal cord imaging and collection of accumulated blood.

The skin was dissected 1-2 vertebrae cranially and 1-2 vertebrae in the caudal area of the injury. Then, the fascia was dissected with a coagulator along the same length. The longest and multifidus muscles were dissected bluntly. The spinous processes were skeletonized from the side of the hemilaminectomy (separating the multifidus muscles with a rasp), the arch of the vertebra, articular processes, pedicles of the arch, transverse or transverse costal processes. When isolating the articular processes, it is necessary to cut the muscles as close to the joint as possible. Into the cranial and caudal wound site, Gelpi retractors were installed. Bleeding was stopped with a coagulator, as well as tight tamponade with $3 \%$ hydrogen peroxide or warm saline solution. The bow was removed either with a high-speed bur or, more often, with a laminectomy (Kerrison's nippers) and Jansen's nippers. At the same time, the pressure was not allowed with the instrument on the spinal cord. After the arch was removed, the spinal canal was revised. The wound was sutured in layers.

This figure shows a view of the final stage of the operation and the removed foreign body (bullet).

Subsequently, an X-ray examination was performed after surgery (Fig. 5).

This figure shows an X-ray of a cat 53 days after the surgery. It can be seen that the lumen of the spinal canal is preserved.

In the postoperative period as an anti-inflammatory drug was used "Meloxi-

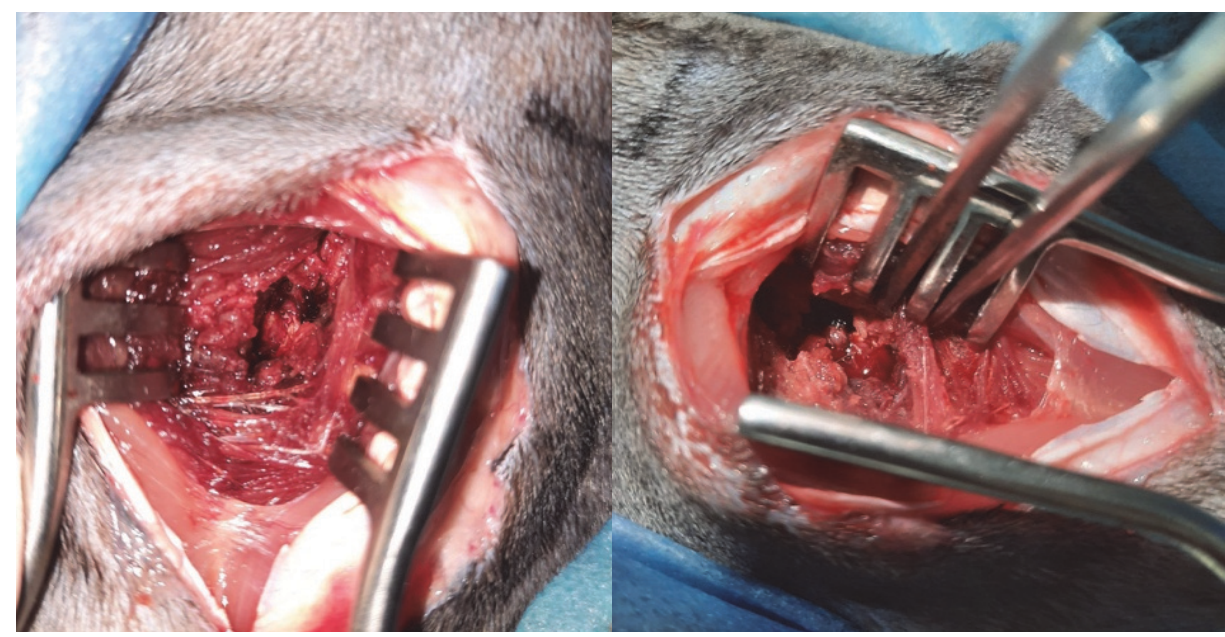

Fig. 3. Stages of laminectomy 


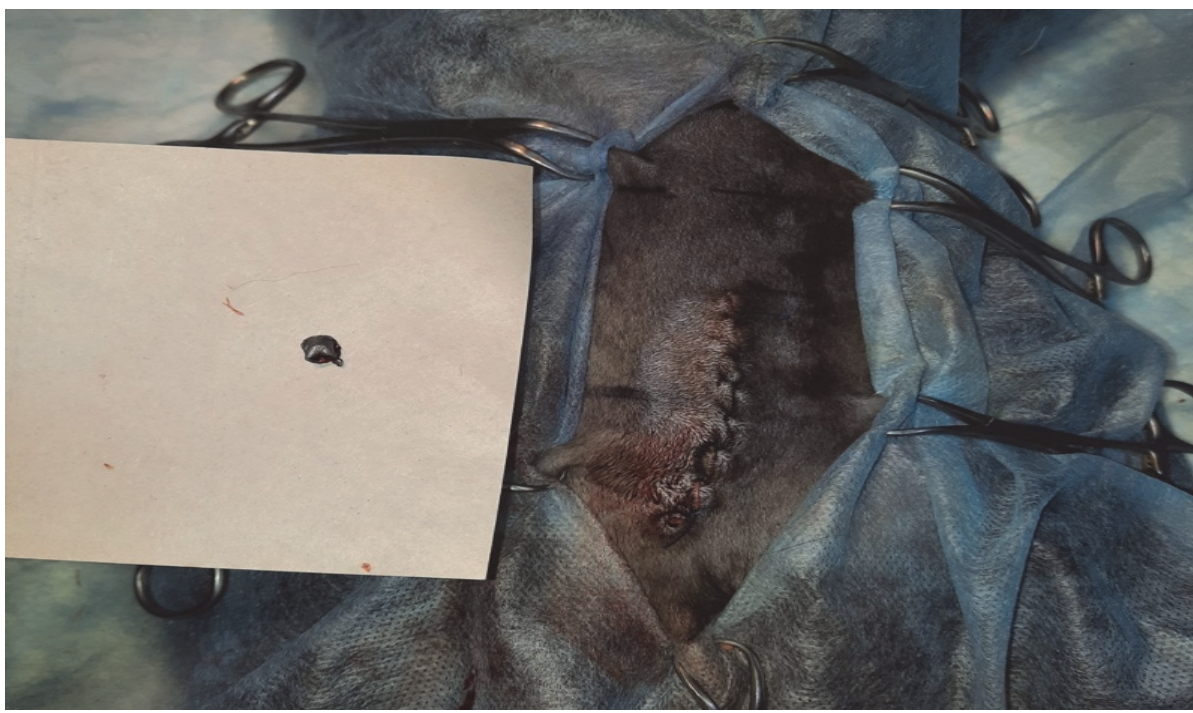

Fig. 4. Removed foreign body (bullet)

cam" at a dose of $0.2 \mathrm{mg} / \mathrm{kg}$ body weight of the animal for 3 days, for postoperative analgesia was used the drug "Butorphanol" at a dose of $0.1 \mathrm{mg} / \mathrm{kg}$ body weight for 5 days. To accelerate the reparative processes in the injured spinal cord was used vitamin preparation "Neurorubin" at a dose of $0.2 \mathrm{ml} / \mathrm{kg}$ body weight of the animal, once a day for only 12 days. For the next 30 days the animal was re- stricted in movement, and after suturing (10 days) was a course of special physical rehabilitation exercises, as well as massage and physiotherapy procedures (iontophoresis with lidocaine, and ultrasonic heating). In 14 days after the surgical intervention, the animal fully restored its independent excretory functions (urination and defecation). After 28 days, a shaky gait was registered in the animal.

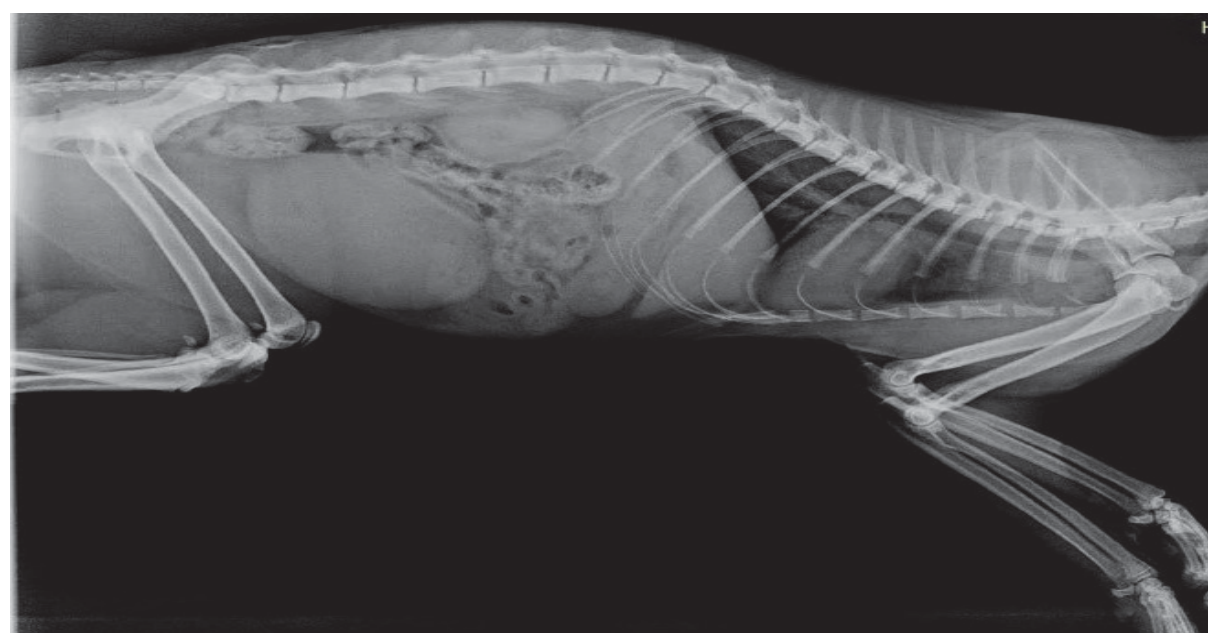

Fig. 5. Radiography of the spine in lateral projection after surgery 
Complete recovery of motor activity in the animal was registered on the 53rd day after surgery.

\section{Conclusions and future perspectives}

The most appropriate for the diagnosis and control of the treatment results for spinal cord injuries in cats is an X-ray examination of the damaged areas in lateral and dorsoventral projections using an X-ray contrast agents (myelography). Laminectomy is an effective method for treating spine trauma and spinal cord injuries in cats. The restoration of the functional state of the animal requires a comprehensive application of rehabilitation measures, such as control of motor activity of the animal (namely its restriction), massage, physiotherapy procedures aimed at reducing pain and improving blood circulation to the injured area.

\section{References}

Ahn, S. Y., Yoon, H. Y., \& Jeong, S. W. (2015). A Case of Gunshot Injury to the Spinal Cord in a Cat: Clinical, Surgical, and Computed Tomographic Features. Journal of Veterinary Clinics, 32(2), 187-190. doi: 10.17555/jvc.2015.04.32.2.187

Colveiro, A. C., Rauber, J. S., Ripplinger, A., Wrzesinski, M., Schwab, M. L., Pigatto, A., ... \& Mazzanti, A. (2020). Neurological and orthopedic diseases in dogs and cats submitted to physiotherapy. Acta Scientiae Veterinariae, 48. doi: 10.22456/1679-9216.103615.

DiFazio, J., \& Fletcher, D. J. (2013). Updates in the management of the small animal patient with neurologic trauma. Veterinary clinic of north America small animal practice, 43(4), 915-940. doi: 10.1016/j.cvsm.2013.03.002

Gordon-Evans W. (2016). Hemilaminetomy. Complications in Small Animal surgery, 86. doi: 10.1002/9781119421344.ch86
Jeffery, N. D. (2010). Vertebral fracture and luxation in small animals.Vet Clinic North Am Small Animal Practice, 40(5), 809-828. doi: 10.1016/j.cvsm. 2010.05.004

Johnson, A. (2005). Hemilaminectomy. In A. L. Johnson, D. Dunning (Eds), Atlas of orthopedic surgical procedures of the dog and cat (pp. 226-229). Elsevier Health Sciences. doi: 10.1016/B978-0-7216-9381-1.50088-0.

Knipe, M. F., Vernau, K. M., Hornof, W. J., \& Lecouteur, R. A. (2001). Intervertebral disc extrusion in six cats. Journal of Feline Medicine \& Surgery, 3(3), 161-168. doi: 10.1053/ jfms.2001.0131

Kranenburg, H.C., Meij, B. P., van Hofwegen, E. M., Voorhout, G., Slingerland, L. I., Picavet, P., \& Hazewinkel, H. A. (2012). Prevalence of spondylosis deformans in the feline spine and correlation with owner-perceived behavioural changes. Veterinary and Comparative Orthopaedics and Traumatology, 25(03), 217-223. doi: 10.3415/VCOT-11-06-0092

Mistieri, M. L. D. A., Grevel, V., Padilha Filho, J. G., Rached, P. A., Ludewig, E., \& Canola, J. C. (2004). Hemilaminectomy in the treatment of vertebral osteochondromatosis in a cat. Ciência Rural, 34(6), 1953-1956. doi: 10.1590/S0103-84782004000600045.

Olby, N., Platt, S., \& Garosi, L. (2012). Spinal trauma. In S. Platt, L. Garosi (Eds). Small animal neurological emergencies, (383-398). London, UK: Manson Publishing/The Veterinary Press. doi: 10.1111/avj.12050

Roberts, R. E., \& Selcer, B. A. (1993). Myelography and epidurography. Veterinary Clinics of North America: Small Animal Practice, 23(2), 307-329. doi: 10.1016/ S0195-5616(93)50030-X

Schur, D., Rademacher, N., Vasanjee, S., McLaughlin, L., \& Gaschen, L. (2010). Spinal cord compression in a cat due to vertebral angiomatosis. Journal of feline medicine and surgery, 12(2), 179-182. doi: 10.1016/j.jfsm.2009.10.003

Sharp, N. J. H., \& Wheeler, S. J. (2005). Trauma. In S. J. Wheeler, N. J. H. Sharp (Eds). Small animal spinal disorders diagnosis and sur- 
gery, 281-318. Edinburgh, NY: Elsevier Mosby. doi: 10.1111/j.1748-5827.2006.00220.x Shores, A., \& Brisson, B. A. (2017). Thoracolumbar hemilaminectomy. Current techniques in canine and feline neurosurgery, 20. doi: 10.1002/9781118711545.ch20

Plunkett, S. J. (2013).Traumatic Emergencies. In S. J. Plunkett (Ed). Emergency procedures for the small animal veterinarian (pp. 4871). Elsevier Health Sciences. doi: 10.1016/ B978-0-7020-2487-0.50007-1

Wise J K, Heath cott BL, G onzale z ML. Resu Its of the AVMA survey on companion animal ownership in US pet-owning households. American Veterinary Medical Association. J
Am Vet Med Assoc 2002; 221: 1572-1573.

Vine, K. (2020). Rehabilitation and recovery times for canine patients post hemilaminectomy. The Veterinary Nurse, 11, 422425. doi: 10.12968/vetn.2020.11.9.422.

Yadhati, A., Kurra, S., \& Tallarico, A. (2017). Lumbar vertebral body and pars fractures following laminectomy. Journal Surgical Case Reports, 2, 1-3. doi: 10.1093/jscr/rjx007

Zamprogno, H., Hansen, B. D., \& Bondell, H. D. (2010). Item generation and design testing of a questionnaire to assess degenerative joint disease-associated pain in cats. American Journal Veterinary Research, 71, 14171424. doi: 10.2460/ajvr.71.12

\section{В.О. Дорощук, А. І. Сокол (2021). КЛІНІЧНИЙ ВИПАДОК ЛІКУВАННЯ ТРАВМА-} ТИЗАЦІї ХРЕБТА ТА СПИННОГО МОЗКУ У КОТА. Ukrainian Journal of Veterinary Sciences, 12(1): 32-39, https://doi.org/10.31548/ujvs2021.01.004

Анотація. У статті висвітлено клінічний випадок травми хребта з ушкодженням спинного мозку в кота. Було встановлено діагноз кульове поранення поперекового відділу хребта з компресією спинного мозку. Було виконано дорсальну ламінектомію із видаленням кулі на рівні L3-L5. Оперативне втручання було виконано без ускладнень із повним одужанням тварини через 2 місяці.

Оскільки за травм спинного мозку без глибокого сприйняттяя болю прогноз функціонального відновлення залишається обережним, оскільки функції спинного мозку повністю заблоковані, необхідно зважати на те, що ноцицептивні шляхи найбільш стійкі до стиснення та ішемії. Встановлено, що для діагностики й контролю результатів лікування травм хребта і спинного мозку в котів найбільш доцільним $є$ рентгенологічне дослідження ушкоджених ділянок улатеральній і дорсовентральній проекціях із застосуванням рентгенконтрастних речовин (мієлографія).

Ламінектомія, що полягає в частковому або повному видаленні елементу, що спричинює компресійну дію, даючи змогу сформувати додатковий вільний простір для спинномозкових структур є ерективним методом для лікування ушкоджень хребта і травм спинного мозку в котів. Для фіксації хребта і збереження його функцій використовуються додаткові стабілізуючі системи. Ламінектомія дає змогу усунути тиск інших анатомічних структур на спинний мозок тварини й нервові закінчення через резекцію дужок хребців у ділянці ураження, їхніх остистих відростків, міжхребцевих дисків тощо. Для відновлення функціонального стану у тварини необхідне комплексне застосування реабілітаційних заходів, таких як контроль рухової активності тварини (а саме ії обмеження), масаж, фізіотерапевтичні процедури, спрямовані на зменшення болю та покращення кровообігу ушкодженої ділянки.

Ключові слова: хребет, хребець, ламінектомія, кіт, травма, спинний мозок 